Electronic Physician (ISSN: 2008-5842)

http://www.ephysician.ir

August 2016, Volume: 8, Issue: 8, Pages: 2828-2832, DOI: http://dx.doi.org/10.19082/2828

\title{
Rh factor is associated with individual radiosensitivity: A cytogenetic study
}

Meysam Khosravifarsani ${ }^{1}$, Ali Shabestani Monfared ${ }^{2}$, Sajad Borzoueisileh ${ }^{3}$

\begin{abstract}
${ }^{1}$ M.Sc. of Radiobiology and Radiation Protection, MPhil, Cellular and Molecular Biology Research Center, Babol University of Medical Sciences, Babol, Iran

${ }^{2}$ Professor of Medical Physics, Cellular and Molecular Biology Research Center, Babol University of Medical Sciences, Babol, Iran

${ }^{3}$ M.Sc. of Radiobiology and Radiation Protection, Cellular and Molecular Biology Research Center, Babol University of Medical Sciences, Babol, Iran
\end{abstract}

\section{Type of article: Original}

\begin{abstract}
Introduction: Radiosensitivity is an inherent trait, associated with a raised reaction to ionizing radiation on the human body. In radiotherapy and radiation protection fields, individualization of the patient's treatment is one of the main topics. With the goal of determining biomarkers capable of anticipating normal tissue side reactions, we studied the association between the $\mathrm{Rh}$ factor and radiosensitivity.

Methods: This experimental study was carried out from January to June 2014 among 50 normal responders with A blood group (25Rh+ and 25Rh-) between the ages of 22 and 23 in Babol, Iran. Human peripheral blood samples were taken from subjects and, using CBMN assay, the biological effects of gamma irradiation, including the frequency of micronuclei (MN) and nuclear division index (NDI), were measured. A data analysis was performed using SPSS version 18 to determine the independent and paired samples t-tests.

Results: A significant increment occurred in the frequency of MN in group $\mathrm{Rh}+(196 \pm 18.23)$ compared with $\mathrm{Rh}-(169 \pm 17.11)$ following irradiation $(\mathrm{p}<0.001)$.

Conclusions: The $\mathrm{Rh}$ factor might be a predicting marker in an individual's radiosensitivity to ionizing radiations. However, we believe that additional investigations are needed to prove this hypothesis.

Keywords: Radiosensitivity, CBMN assay, Nuclear division index (NDI)
\end{abstract}

\section{Introduction}

Exposure to ionizing radiation generates several reactive oxygen species (ROS), like hydroxyl radical, hydrogen peroxide, aqueous electron, and superoxide in the aqueous medium. Such ROS have harmful effects on macromolecules such as lipids, proteins, and DNA and damages cellular function, leading to multiple disorders and dysfunctions in the human body $(1,2)$. As several studies in the literature have indicated, radiation response is a multi-factorial scenario that depends on several parameters, such as the nuclear material content, cell reproduction, tissue and organ revival, and biological repair. From a biological viewpoint, it is important to consider how radiation response may moderate the responses of tissues and organs to gamma irradiation. From this aspect, genetic properties are highly crucial in most diseases and disorders, such as ataxia-telangiectasia (AT) (3), Xeroderma Pigmentosum (4), and breast cancer (5), and an important characteristic in the radiosensitivity of cells, tissues and organs (5). Approximately $10 \%$ of normal individuals in similar physical and environmental conditions exhibit incremented response to ionizing radiations (6). Increased radiosensitivity of breast cancer patients has been reported in several different studies (7-9). Hence, identifying a prognostic marker for radiotherapy is one of the main goals of the radiation biology and radiation protection field. If the personal complication risks of ionizing radiation are recognized, the risk could be reduced in the small ratio of highly sensitive people through dose reduction in patients and the defining of more limited rules in radiation protection regulations (10). Some origins of

\section{Corresponding author:}

Professor Dr. Ali Shabestani Monfared, Medical Physics Department, Faculty of Medicine, Babol University of Medical Sciences, Babol, Iran. Tel: +98.9111230475, Fax: +98.1125289733, Email: monfared1345@gmail.com

Received: March 08, 2016, Accepted: May 28, 2016, Published: August 2016

iThenticate screening: May 28, 2016, English editing: July 21, 2016, Quality control: August 02, 2016

(C) 2016 The Authors. This is an open access article under the terms of the Creative Commons Attribution-NonCommercialNoDerivs License, which permits use and distribution in any medium, provided the original work is properly cited, the use is non-commercial and no modifications or adaptations are made. 
radiosensitivity, including physiological, genetic, and epigenetic sources, have been proposed in cancer patients and normal individuals $(11,12)$. Several studies have marked that ABO blood groups are associated with the risk of ischemic heart disease and developing severe manifestation of atherosclerosis (13). Results from the Framingham study and other reports showed the occurrence of ischemic heart disease might be higher in subjects with blood group A (13). In addition, patients with blood groups A or O are more often afflicted with pernicious anemia (14). The incidences of gastric carcinoma (15), peptic ulcer (16), and ovarian cancer (5) are much more extensive in persons with blood types $\mathrm{A}, \mathrm{O}$, and $\mathrm{B}$, respectively. The $\mathrm{AB}$ blood group is associated with an incremented risk of infectious disease. Nonetheless, it was explained that the ABO blood group is an inherent characteristic (17). Thereafter, the alleles for the blood groups were recognized in the same place on chromosome 9 at $9 \mathrm{q} 34.1-\mathrm{q} 34.2$ (18). These findings demonstrated that one's blood group is a genetic trait. Despite such investigations, a preliminary clinical study showed that the radiation response of type $\mathrm{O}$ patients suffering from carcinoma of the cervix is better than those of other blood groups (19). Meanwhile, an elevated frequency of micronuclei (MN) in the A blood group was reported in peripheral blood lymphocytes of normal individuals (20). Regarding these findingsand given the variation in radiosensitivity in the normal population-this study aimed to evaluate chromosomal radiosensitivity of peripheral blood lymphocytes in normal individuals with $\mathrm{Rh}^{-}$and $\mathrm{Rh}^{+}$factors.

\section{Material and Methods}

\subsection{Research design and setting}

In this experimental study, informed consent was acquired from 50 healthy human volunteers ( $25 \mathrm{Rh}+$ and $25 \mathrm{Rh}-)$ in the A blood group who ranged in age from 22 to 23 years old.

\subsection{Blood sampling}

All responders completed a questionnaire to provide information on their lifestyle and exposure to chemical and physical agents. Having a history of known irradiation, smoking, drug treatment, and alcohol consumption were exclusion criteria. Blood samples were taken from responders under sterile conditions using heparinized syringes. Finally, samples were divided into two separate groups (control and exposed blood samples). All of them were transferred in cold environmental conditions.

\subsection{Gamma irradiation}

The aliquots of blood samples were exposed to gamma radiation of a low LET ${ }^{60} \mathrm{Co}$ source (Theratone780 manufactured by Canada) at dose rate of $70 \mathrm{CGy} / \mathrm{min}$, with source-to-sample distance (SSD) $=80 \mathrm{~cm}$, a field size of $10 \times 10 \mathrm{~cm}$, and at room temperature. Blood samples were irradiated with a total dose of $2 \mathrm{~Gy}$, and a vial of unexposed blood samples was kept as the control group. The sample irradiation was performed by an authorized person.

\subsection{Cytokinesis-block micronucleus (CBMN) assay}

The CBMN assay was carried out using the standard technique proposed by earlier investigations (21), with minor modifications (22). Hence, $0.5 \mathrm{ml}$ of peripheral blood samples were added to $4.5 \mathrm{ml}$ of a cell culture medium (RPMI1640) containing sodium bicarbonate supplemented with $10 \%$ fetal calf serum (FCS), antibiotics, and 1\% Lglutamine. One hundred microliters of Phytohaemagglutinin (PHA, SIGMA) was added to stimulate lymphocytes. Forty-four hours after PHA stimulation, Cytochalasin-B (Cyt-B, Sigma) at a final concentration of $6 \mu \mathrm{g} / \mathrm{ml}$ was added, and binucleated lymphocytes were harvested after $72 \mathrm{~h}$. The cells were then collected by centrifugation at 2,000 RPM for $10 \mathrm{~min}$ (BOECHO U-320 R), and supernatant was decanted. Two to three microliters of fresh hypotonic solution $0.075 \mathrm{M} \mathrm{KCl}$ was added to the solution remaining at the bottom of tubes and centrifuged at 1,200 RPM for $7 \mathrm{~min}$. Again, the supernatant was poured off, and $5 \mathrm{ml}$ of fixature including methanol:glacial acetic acid $(6 / 1)$ were quickly mixed with solution at the bottom of the tubes. After $20 \mathrm{~min}$, the tubes were centrifuged at 1,200 RPM for $7 \mathrm{~min}$. the induction of MN was evaluated using a double-blind score of 1000 binucleated cells (BNC) with a light microscope set to 40x magnification. Only BN cells were included in the microscopic analysis. All slides were coded before analysis.

\subsection{Statistical analysis}

The statistical analysis was carried out using Microsoft Excel 2007. Independent-Sample t-test was used to determine the statistical significance of the difference between $\mathrm{Rh}^{-}$and $\mathrm{Rh}^{+}$samples. In addition, a paired-samples ttest was used to analyze the difference between the control and exposed samples. 


\subsection{Research ethics}

The study was approved by the Ethical Committee of the Faculty of Medical Sciences at Babol University of Medical Sciences (Babol, Iran).

\section{Results}

The results of this study showed an increased mean frequency of $\mathrm{MN}$ in binucleated cells after irradiation (Figure 1). This result confirms the induction of MN frequency following gamma irradiation. As Table 1 shows, the mean values of MN in binucleated cells were $196 \pm 18.23$ and $169 \pm 17.11$ for $\mathrm{Rh}^{+}$and $\mathrm{Rh}^{-}$samples, respectively (Table 1). The results indicated that the average $M N$ is significantly higher in $\mathrm{Rh}^{+}$than in $\mathrm{Rh}^{-}$in the irradiated group $(\mathrm{p}<0.001)$ (Table 1). Table 2 shows that the frequency of MN cells significantly increased in both $\mathrm{Rh}^{-}$and $\mathrm{Rh}^{+}$ irradiated (2Gy) samples whereas the percentage of binucleated, trinucleated, and tetranucleated cells decreased after irradiation. The NDI value for the $\mathrm{Rh}^{+}$group was 1.81 and 1.39 before and after irradiation, respectively. For the $\mathrm{Rh}^{-}$type, the parameter declined from 1.85 to 1.40 following gamma irradiation. Regarding the NDI in Table 2, no significant difference emerged between $\mathrm{Rh}^{-}$and $\mathrm{Rh}^{+}$samples after irradiation.

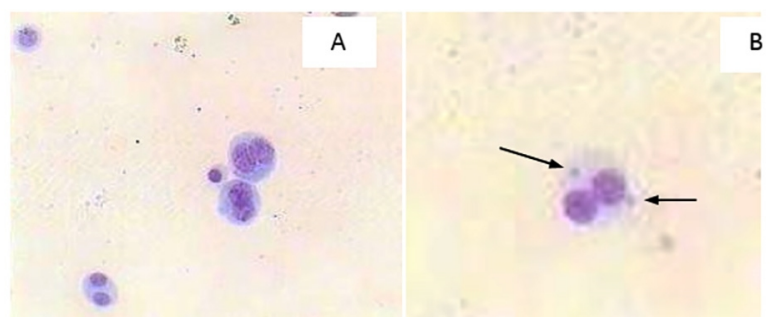

Figure 1. Increased frequency of micronuclei (MN) in both $\mathrm{Rh}$ - and $\mathrm{Rh}+$ samples after gamma irradiation (2Gy). A: Mononuclear and binuclear lymphocyte cells before irradiation, B: Binuclear lymphocyte cell bearing MN. Arrows show the appearance of $\mathrm{MN}$ during gamma irradiation.

Table 1. Frequency of micronuclei (MN) in binucleated cells (BNC)

\begin{tabular}{|l|l|l|}
\hline \multirow{2}{*}{ Dose } & \multicolumn{3}{|l|}{$\mathrm{MN}$ (micronuclei) Yield in BNC (binucleated cells) } \\
\cline { 2 - 3 } & $\mathrm{Rh}^{+}$ & $\mathrm{Rh}^{-}$ \\
\hline $0 \mathrm{~Gy}$ & $3.75 \pm 0.53$ & $5.35 \pm 0.90$ \\
\hline 2Gy & $196 \pm 18.23$ & $169 \pm 17.11$ \\
\hline
\end{tabular}

Table 2. Percentage of mononucleated (MNC), binucleated (BNC), trinucleated (TNC), and tetranucleated (TeNC) cells in non-exposed (0Gy) and exposed (2Gy) samples. NDI $=\mathrm{M} 1+2(\mathrm{M} 2)+3(\mathrm{M} 3)+4(\mathrm{M} 4) / \mathrm{N}$, where M1-M4 presents the number of cells with one to four nuclei and $N$ is the total number of viable cells.

\begin{tabular}{|l|l|l|l|l|l|l|l|l|l|l|}
\hline \multirow{2}{*}{ Dose } & \multicolumn{2}{l}{$\begin{array}{l}\text { Mononucleated cells } \\
\text { (MNC) (\%) }\end{array}$} & \multicolumn{2}{l|}{$\begin{array}{l}\text { Binucleated cells } \\
(\mathrm{BNC})(\%)\end{array}$} & \multicolumn{2}{l|}{$\begin{array}{l}\text { Trinucleated cells } \\
(\mathrm{TNC})(\%)\end{array}$} & \multicolumn{2}{l|}{$\begin{array}{l}\text { Tetranucleated cells } \\
(\mathrm{TeNC})(\%)\end{array}$} & \multicolumn{2}{l|}{$\begin{array}{l}\text { Nuclear Division } \\
\text { Index (NDI) }\end{array}$} \\
\cline { 2 - 12 } & $\mathrm{Rh}^{+}$ & $\mathrm{Rh}^{-}$ & $\mathrm{Rh}^{+}$ & $\mathrm{Rh}^{-}$ & $\mathrm{Rh}+$ & $\mathrm{Rh}^{-}$ & $\mathrm{Rh}^{+}$ & $\mathrm{Rh}^{-}$ & $\mathrm{Rh}^{+}$ & $\mathrm{Rh}^{-}$ \\
\hline $0 \mathrm{~Gy}$ & 45.1 & 38.3 & 34.1 & 40.4 & 15.2 & 19.1 & 5.6 & 2.2 & 1.81 & 1.85 \\
\hline $2 \mathrm{~Gy}$ & 70.6 & 69.7 & 20.1 & 21.2 & 8.2 & 8.4 & 1.1 & 0.7 & 1.39 & 1.40 \\
\hline
\end{tabular}

\section{Discussion}

Approximately $20 \%$ of the radiotherapy patients showed a wide range of normal tissue reactions (23). Recognizing patients with high, moderate, or low radiosensitivity would help develop a good plan for the radiotherapy of patients with the highest cure rate in terms of the patient's individual adaptation (10). The explanation of criteria that modify the total effects of ionizing radiation is one of the main subjects of research efforts in radiobiology. Some studies have explained that a correlation exists between tumor response and the level of 8-oxo-dG in the urine of lung and breast cancer patients (23). Hence, several studies have been initiated to investigate whether radiosensitivity is an individualized subject in patients' radiation response. The main purpose of this study was to investigate the role of $\mathrm{Rh}$ in radiation response of healthy people. Hoeller et al. showed that individual radiosensitivity measured by lymphocytes might be a good way to predict fibrosis in breast cancer patients after radiotherapy (24). In the field of radiobiology, the CBMN Cyt assay for PBL is a suitable bio-dosimetry device to measure in-vivo and in-vitro radiosensitivity and cancer reproducibility (25). Lymphocytes are chosen because of their easy availability, simple method of culture, and ease of sample collection. Therefore, in our study, CBMN Cyt assay as one of the standard techniques for genetic toxicology evaluation in human cells was selected to measure chromosomal aberrations in $\mathrm{Rh}^{-}$ 
and $\mathrm{Rh}^{+}$healthy people. As expected, the average number of $\mathrm{MN}$ increased significantly after the $2 \mathrm{~Gy}$ gamma irradiation of lymphocyte cells. This result concurs with the earlier findings indicating a higher level of MN after gamma irradiation $(21,26)$. The current study showed that the mean frequency of $\mathrm{MN}$ in the $\mathrm{Rh}^{+}$group was roughly $16 \%$ higher than in the $\mathrm{Rh}^{-}$group. This result might be due to the association of $\mathrm{Rh}$ alleles on chromosome 9 and particular alleles of genes responsible for DNA double strand break repair. However, more molecular investigations need to evaluate more precisely the main reason for this event. Elahimanesh et al. indicated that the A blood group has more MN frequency compared to other blood types (20). They showed that group A has a higher frequency of $\mathrm{MN}$ than did groups $\mathrm{AB}, \mathrm{B}$, and $\mathrm{O}(20)$. In another study, Khosravifarsani et al. elucidated that an association exists between handedness and radiosensitivity. They showed that left-handed breast cancer women are more radiosensitive than right-handed women (18). The background $\mathrm{MN}$ frequency in the present study was $3.75 \pm 0.53$ and $5.35 \pm 0.90$ for the $\mathrm{Rh}^{+}$and $\mathrm{Rh}^{-}$groups, respectively. This value is in fair agreement with the cited value of IAEA EPR bio-dosimetry manual by International Atomic Energy Agency (27). Regarding the IAEA report, the background MN frequencies range from 0 to 40 per $1000 \mathrm{BN}$ cells (27). For the NDI counted prior to and after irradiation, the value decreased in both $\mathrm{Rh}^{+}$and $\mathrm{Rh}^{-}$groups after 2Gy gamma irradiation, indicating a reduction in cell proliferation. However, no significant difference occurred between these two blood types after irradiation. As the present study indicated, a decrease yield of binucleated and polynucleated cells was observed after gamma irradiation. In contrast, the frequency of mononucleated cells increased after gamma irradiation. Because carrying out standard Cytokinesis Blocked Micro-nuclei protocol was time consuming, choosing a larger study population was restricted in this project.

\section{Conclusions}

The present study suggested that chromosomal radiosensitivity of lymphocytes in normal individuals with $\mathrm{Rh}^{+}$ factor is higher than their $\mathrm{Rh}^{-}$counterparts. However, this difference is not generalized to other types of cells. This finding revealed that the $\mathrm{Rh}$ factor can be considered one of the hereditary traits affecting individuals' radiosensitivity and can be a valuable item in radiation protection regulations. However, further in-vivo and in-vitro studies are needed for validation.

\section{Acknowledgments:}

This work was derived from a research project and financially supported by the Babol University of Medical Sciences (Grant Number 2140). The authors would like to express their gratitude to Miss Nasim Koohi and Mrs. Boshra Rezaei for their contributions during the work at the Cellular and Molecular Biology Research Center, all healthy individuals for their blood donations, and Shahid Rajaei Hospital staff for their warm-hearted cooperation in the gamma irradiation of samples.

\section{Conflict of Interest:}

There is no conflict of interest to be declared.

\section{Authors' contributions:}

All authors contributed to this project and article equally. All authors read and approved the final manuscript.

\section{References:}

1) Cho EJ, Yokozawa T, Rhyu DY, Kim HY, Shibahara N, Park JC. The inhibitory effects of 12 medicinal plants and their component compounds on lipid peroxidation. Am J Chin Med. 2003; 31(6): 907-17. doi: 10.1142/s0192415x03001648. PMID: 14992543.

2) Spitz DR, Azzam EI, Li JJ, Gius D. Metabolic oxidation/reduction reactions and cellular responses to ionizing radiation: a unifying concept in stress response biology. Cancer Metastasis Rev. 2004; 23(3-4): 311-22. doi: 10.1023/B:CANC.0000031769.14728.bc. PMID: 15197331.

3) Painter RB, Young BR. Radiosensitivity in ataxia-telangiectasia: a new explanation. Proc Natl Acad Sci U S A. 1980; 77(12): 7315-7. PMID: 6938978, PMCID: PMC350493.

4) Bootsma D, Hoeijmakers JH. The genetic basis of xeroderma pigmentosum. Ann Genet. 1990; 34(3-4): 143-50. PMID: 1809220.

5) Henderson L, Kitzinger J. The human drama of genetics: 'hard' and 'soft' media representations of inherited breast cancer. Sociology of Health \& Illness. 1999; 21(5): 560-78. doi: 10.1111/14679566.00173 . 
6) Mozdarani H, Ziaee Mashhadi AH, Alimohammadi Z. G2 chromosomal radiosensitivity and background frequency of sister chromatid exchanges of peripheral blood lymphocytes of breast cancer patients. Internatuinal Journal of Radiation Research. 2011; 9(3): 167-74.

7) Parshad R, Price FM, Bohr VA, Cowans KH, Zujewski JA, Sanford KK. Deficient DNA repair capacity, a predisposing factor in breast cancer. $\mathrm{Br} \mathrm{J}$ Cancer. 1996; 74(1): 1-5. PMID: 8679441, PMCID: PMC2074608.

8) Patel RK, Trivedi AH, Arora DC, Bhatavdekar JM, Patel DD. DNA repair proficiency in breast cancer patients and their first-degree relatives. Int J Cancer. 1997; 73(1): 20-24. doi: 10.1002/(SICI)10970215(19970926)73:1<20::AID-IJC4>3.0.CO;2-3. PMID: 9334804.

9) Scott D, Spreadborough A, Levine E, Roberts SA. Genetic predisposition in breast cancer. Lancet. 1994; 344(8934): 1444.

10) Ghasemi SH, Shabestani Monfared A, Borzoueisileh S, Zabihi E, Amiri M, Abedian S, et al. Predicting Factors of Radiosensitivity in Individual Radiotherapy. Journal of Babol University of Medical Sciencses. 2015; 17(10): 67-73.

11) Crompton NE, Shi YQ, Emery GC, Wisser L, Blattmann H, Maier A, et al. Sources of variation in patient response to radiation treatment. Int J Radiat Oncol Biol Phys. 2001; 49(2): 547-54. doi: 10.1016/S03603016(00)01477-2. PMID: 11173153.

12) Tursen U, Tiftik EN, Unal S, Gunduz O, Kaya TI, Camdeviren H, et al. Relationship between ABO blood groups and skin cancers. Dermatol Online J. 2005; 11(3): 44. PMID: 16409940.

13) Vivek S, Jain J, Simon SP, Battur H, Supreetha S, Haridas R. Association of ABO Blood Group and Rh factor with Periodontal Disease in a Population of Virajpet, Karnataka: A Cross-Sectional Study. J Int Oral Health. 2013; 5(4): 30-4. PMID: 24155617, PMCID: PMC3780381.

14) Aird I, Bental HH, Bingham J. AN ASSOCIATION between blood group A and pernicious anaemia; a collective series from a number of centres. Br Med J. 1956; 2(4995): 723-4. doi: 10.1136/bmj.2.4995.723. PMID: 13364309, PMCID: PMC2035389.

15) Callender S, Langman MJ, Macleod IN, Mosbech J, Nielsen KR. ABO blood groups in patients with gastric carcinoma associated with pernicious anaemia. Gut. 1971; 12(6): 465-7. doi: 10.1136/gut.12.6.465. PMID: 5090871, PMCID: PMC1411666.

16) Clarke CA. Correlations of ABO Blood Groups with Peptic Ulcer, Cancer, and Other Diseases. Am J Hum Genet. 1959; 11(2 Pt 2): 400-4. PMID: 17948441, PMCID: PMC1932162.

17) Schwarz HP, Dorner F. Karl landsteiner and his major contributions to haematology. Br J Haematol. 2003; 121(4): 556-65. doi:10.1046/j.1365-2141.2003.04295.x. PMID: 12752096.

18) Dean L. Blood Groups and Red Cell Antigens. US, National Center for Biotechnology Information. 2005.

19) Garriga R, Ghossein NA. The ABO blood groups and their relation to the radiation response in carcinoma of the cervix. Cancer. 1963; 16: 170-2. doi: 10.1002/1097-0142(196302)16:2<170:AIDCNCR2820160205>3.0.CO;2-X. PMID: 13946637.

20) Elahimanesh F, Shabestani Monfared A, Khosravifarsani M, Akhavan Niaki H, Abedian Z, Hajian-Tilaki $\mathrm{K}$, et al. Is radiosensitivity associated to different types of blood groups? (A cytogenetic study). Int J Mol Cell Med. 2013; 2(3): 131-5. PMID: 24551803, PMCID: PMC3920532.

21) Henderson J, Seagroatt V, Goldacre M. Ovarian cancer and ABO blood groups. J Epidemiol Community Health. 1993; 47(4): 287-9. doi: 10.1136/jech.47.4.287. PMID: 8228763, PMCID: PMC1059794.

22) Haghdoost S. Biomarkers of Oxidative Stress and Their Application for Assessment of Individual Radiosensititvity. Stockholm University, Faculty of Science, Department of Genetics, Microbiology and Toxicology. Doctoral thesis. 2005.

23) Hoeller U, Borgmann K, Bonacker M, Kuhlmey A, Bajrovic A, Jung H, et al. Individual radiosensitivity measured with lymphocytes may be used to predict the risk of fibrosis after radiotherapy for breast cancer. Radiother Oncol. 2003; 69(2): 137-44. doi: 10.1016j.radonc.2003.10.001. PMID: 14643950.

24) Gajski G, Milković D, Ranogajec-Komor M, Miljanić S, Garaj-Vrhovac V. Application of dosimetry systems and cytogenetic status of the child population exposed to diagnostic X-rays by use of the cytokinesis-block micronucleus cytome assay. J Appl Toxicol. 2011; 31(7): 608-17. doi: 10.1002/jat.1603. PMID: 21089162.

25) Moghbeli-Nejad S, Mozdarani H, Aleyasin A. Increased frequency of micronuclei in lymphocytes of infertile males after exposure to gamma irradiation: a possible sign of genomic instability. J Assist Reprod Genet. 2012; 29(1): 89-94. doi: 10.1007/s10815-011-9550-8. PMID: 21365452, PMCID: PMC3252411.

26) International Atomic Energy Agency (IAEA). Operations Manual for Incident and Emergency Communication. Vienna, Vienna International Centre. 2012. 